\title{
Implementation of a distance learning program focused on continuing medical education with the support of patent-based data mining
}

Implementation of a DL program

Received 12 November 2018 Revised 28 July 2019 Accepted 9 August 2019

\author{
Renato Ribeiro Nogueira Ferraz
}

Graduate Program in Public Policy (PPG-PP), Universidade de Mogi das Cruzes, Mogi das Cruzes, Brazil

Marcus Vinícius Cesso da Silva

Graduate Program in Administration (PPGA), Universidade Nove de Julho (UNINOVE), São Paulo, Brazil

Renan Antônio da Silva

Graduate Program in Public Policy (PPG-PP),

Universidade de Mogi das Cruzes, Mogi das Cruzes, Brazil, and

Luc Quoniam

Graduate Program in Law,

Universidade Federal de Mato Grosso do Sul, Campo Grande, Brazil and

Department of Interactions, Milieux, Medias, I3M, EA3820,

Universite de Toulon, La Garde, France

\begin{abstract}
Purpose - The purpose of this paper is to present the use of a free code computational tool, Patent2net, in the search of patents for the implementation of distance learning aimed at Continuing Medical Education.

Design/methodology/approach - This technical report is based on the extraction, organization and availability, in the format of graphs and dynamic tables, and also based on information in other patents on the subject, made available in the Espacenet database.

Findings - As a result, it was possible to identify a Chinese patent, free for reproduction in Brazil, which describes an e-learning system that simulates 3D scenarios for training nursing teams.

Research limitations/implications - The paper has used one unique patent database, but containing more than $100 \mathrm{~m}$ documents.

Practical implications - The selected patent can contribute to the improvement of care and behavioral techniques of the health professionals.

Social implications - The training of health professionals can improve the public and supplementary health systems.

Originality/value - This is the first paper in that de technometric analisys of patents was used to solve a problem regarding the training of health professionals.

Keywords Patents, Innovation

Paper type Technical paper

(C) Renato Ribeiro Nogueira Ferraz, Marcus Vinícius Cesso da Silva, Renan Antônio da Silva and Luc Quoniam. Published in Revista de Gestão. Published by Emerald Publishing Limited. This article is published under the Creative Commons Attribution (CC BY 4.0) licence. Anyone may reproduce, distribute, translate and create derivative works of this article (for both commercial and non-commercial purposes), subject to full attribution to the original publication and authors. The full terms of this licence may be seen at http://creativecommons.org/licences/by/4.0/legalcode
\end{abstract}

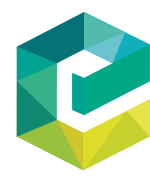

Revista de Gestão Vol. 27 No. 1, 2020 pp. $37-60$ Emerald Publishing Limited e-ISSN: $2177-8736$ p-ISSN: $1809-2276$ DOI 10.1108/REGE-11-2018-0108 
REGE 27,1

\section{Introduction}

The study of patents can be considered important since these documents constitute a vast source of information and technological knowledge, reporting innovations and inventions in the most varied subjects and sectors (Bergek et al., 2015). It is through them that new technologies are discovered, relations between companies and inventors are established, nations with superior innovation development and data protection are identified, and the main research and development centers of the world are mapped (Ferraz, Quoniam, Reymond, \& Maccari, 2016).

Given the importance of the subject, and due to the economic impact on nations (Lastres, Cassiolato, Lemos, Maldonado, \& Vargas, 1999), several authors have published research on patent innovation (Morescalchi, Pammolli, Penner, Petersen, \& Riccaboni, 2015), patent-mining technologies (Larose, 2014; Tseng, Lin, \& Lin, 2007), patent networks (White, 2006) and their use in the academic community (Corrêa \& Gomes, 2013; Quoniam, Kniess, \& Mazzieri, 2014; Simões, Baessa, Campolina, \& Silva, 2002).

However, Storopoli (2016) reported that there are few studies related to patents and distance learning (DL), and this number is further reduced when trying to identify DL patents for continuing medical education (Hassanzadeh, Kanaani, \& Elahi, 2012; Hung, 2012). Thus, to address this shortage, the present study addresses the following question: "How can we increase and disseminate knowledge in DL patents in the area of continuing medical education using a data mining tool?"

In order to answer this question, this paper uses a qualitative research method - with a descriptive character - to demonstrate how information about DL patents related to continuing medical education can be extracted, organized and made available, in the form of graphs and dynamic tables.

In this context, the purpose of this paper is to demonstrate how the Patent2net computational tool collects and organizes the massive amounts of information related to DL patents - which is focused on continuing medical education - thus reinforcing its importance as an example of an Open Patent Service (OPS) for the whole society. The automation of the collection and organization of the patent information demonstrates that researchers, as well as any member of society, interested in knowing and/or evaluating technical information present in patent documents, can have access to new technologies. Furthermore, there is, currently, an enormous amount of underutilized data in the databases that make a manual search of these documents nearly impossible, which justifies the use of mining data tools, such as Patent2net. Thus, through the use of this computational tool, information related to patents, previously deposited only in the deep web, becomes easily accessible in dynamic search interfaces available on the surface web, contributing to the expansion of technical and scientific knowledge, which in turn can bring a series of benefits to the nations or corporations that make use of them, promoting the creation of practical improvements in various aspects of daily life.

For this, in addition to this Introduction, the section on Theoretical Framework is presented, which discusses the importance of studying patents in the technological and managerial scope, the models of computational tools used for the search of patents, and the process of data mining of patents using computational tools, as well as an emphasis on the Patent2net tool being used to identify DL patents related to health and education. Next, the section entitled Research methodology is presented, in which the basic search mechanisms and procedures using the Patent2net data mining program are discussed, as well as its application to this work. In the Description and Analysis of Results section, the layout of the web pages generated after the treatment of the patent documents, which were extracted from a worldwide database, Espacenet, with more than $110 \mathrm{~m}$ patent documents are shown. Finally, in the Final Considerations section, we discuss the use of Patent2net for collecting and organizing the information related to DL in continuing medical education patents, discuss the limitations of the research and highlight the gaps that can serve as suggestions for the accomplishment of future studies focused on the theme proposed in the present work. 


\section{Theoretical framework}

In this section, we present the main theoretical pillars that support this work: the concept of patents, the models of computational tools used in searching for, the computational tool Patent2net, DL and continuing medical education.

\subsection{Patent study}

Patents are important sources of information related to new technologies and innovations that, oftentimes, result in social improvements and increases in financial performance, ensure unspoken knowledge of a nation or organization and generate a sustainable competitive advantage in the market (Ferraz et al., 2016). For this reason, the organization of patent databases allows a large amount of constantly updated technological information to remain available for consultation and analysis throughout society (França, 1997). This fact allows for the dissemination of information (Corrêa \& Gomes, 2013; Simões et al., 2002), with the knowledge of the inventors and their organizations evidently respected, since these documents become available in full after the legal period of 18 months of confidentiality, from patent filing to disclosure (Quoniam et al., 2014). It is worth mentioning that databases allow the visualization of patents granted and protected by law, patents that have been denied and which are in turn free to be improved and used by others (Ferraz et al., 2016), as well as patents that were granted but whose protection was not extended to all countries, making their replication legally permissible in these places (Barbieri \& Alvares, 2005).

Identifying patents, both denied and granted, but not extended to other countries for any reason, may lead to a review of technologies and the motivation of incremental innovations on any subject (Serafini, Paixao, Oliveira-Junior, Santos, \& Da Silva, 2012). Additionally, the analysis of these patents brings with it a variety of technological information, often presented superficially in scientific articles (Simões et al., 2002), which can serve as a bibliographical review in future studies on innovation and new technologies (Melo et al., 2014; Quoniam et al., 2014). Another important point regarding patents, granted without extension to other countries, is the possibility of replication in these countries, allowing them to use the innovation described in patent documents to promote radical improvements in their products and processes (Choi \& Heinemann, 2016).

Patents also contribute to the technological and economic development of nations, by assisting in strategic decisions in the public and private sectors (Bergek et al., 2015). Through them, organizations decide whether to act, for example, with open innovations (Chesbrough, 2006), integrating external and internal knowledge (Laursen \& Salter, 2006) or generating innovations. Thus, organizations can establish which dynamic capabilities they have to develop such technologies (Teece, 2007).

Another important point is the positive relationship between patents developed by an organization and its economic evolution in the market (Ernst, 2003). According to Ferraz, Quoniam, Reymond, and Maccari (2016), one way to form this relationship is to analyze the volume of patents developed by this organization, its applicability within the market, the number of citations this patent has and the quantity of bibliographic productions originated from them.

Thus, the study of patents is an interesting way of evaluating the economic performance of a nation (Bergek et al., 2015) or organization (Morescalchi et al., 2015), making it possible to understand the most current technological advances (Aoki \& Schiff, 2008; Bonino, Ciaramella, \& Corno, 2010; Serafini et al., 2012), as well as market innovations (Chesbrough, 2006).

\subsection{Models of computational patent search tools}

The analysis of patent content through textual reading and evaluation has great value for developing countries (Ferraz et al., 2016), as for example, Brazil. To understand this importance, according to Corrêa and Gomes (2013), only 5 percent of innovations protected by patents in developed countries are extended to the others, which mean that 95 percent of the 
REGE 27,1

documents are in the public domain. These patents, in turn, can be legally replicated anywhere and by anyone, which generates a large volume of inventions that can be employed to solve the everyday problems faced by organizations or nations (Quoniam et al., 2014).

Following the 18-month confidentiality period of the patent content (gap of secrecy), any organization or inventor may acquire the information necessary for the replication of the information contained in them. However, the patent documents are deposited in a restricted area of the internet called the deep web (Ferraz et al., 2016), in which the popular search engines cannot function in a way that allows for the joint analysis of the information present in the patent documents, which forces the researcher to analyze each patent one by one, in a fragmented way, making this process time consuming and unproductive. This information needs to be made available in a way that allows for a dynamic analysis, based on indicators related to patents, such as the technologies involved, their inventors, sponsoring companies, protection countries, legal status and number of citations, among others. Additionally, the network relationships among inventors, companies, countries and technologies, as well as their geographical maps are also necessary when utilizing computational tools for patent searches. For this reason, search engines have been coupled with patent databases such as Patentscope (Bonino et al, 2010), Espacenet (Arslan et al., 2006) and Google Patent Search (Aoki \& Schiff, 2008).

According to Bonino, Ciaramella, and Corno (2010), Patentscope is a search engine offered by the World Intellectual Property Organization (WIPO), which allows anyone access to more than $45 \mathrm{~m}$ patents in the world, evaluating the content of each one according to their interest. Google Patent Search, available since 2006, can unify the search for patents in three databases: WIPO, the European Patent Office (EPO) and the United States Patent and Trademark Office, with a total of $8.5 \mathrm{~m}$ patents (Aoki \& Schiff, 2008). Finally, Espacenet, an EPO database, is a computational search tool that grants access to more than $110 \mathrm{~m}$ patents (Arslan et al., 2006), being considered the best patent search application currently, due to the number of documents (Ferraz et al., 2016), geographical scope for the collection of patent data (Jürgens \& Herrero-Solana, 2015) and its user-friendly interface for document search (White, 2006).

\subsection{The process of patent data mining}

The use of computational patent search tools is useful for the extraction, organization and availability of the patent document data, allowing for the concomitant evaluation of a large amount of patent information, based on several indicators such as country of deposit, inventor or technology (Quoniam et al., 2014). Basically, these tools should be able to mine the data so that large amounts of information can be extracted from the deep web and made available for public access on the surface web (Larose, 2014), enabling its organization for researchers and society (Melo et al., 2014).

Since the 1940s, patent research has been carried out by several researchers, beginning in the former Soviet Union, where the TRIZ methodology was developed (Kubota \& da Rosa, 2013). This methodology, which is a theory for inventive problem solving, is still used today by several companies, which rely on TRIZ to develop innovative product portfolios (Laursen \& Salter, 2006).

Presently, the manual analysis of patent documents has become impracticable. For example, for manual analysis of 5,000 patents, based on a validated content analysis methodology, it would take about 112 uninterrupted days for all documents to be verified and have the most relevant information tabulated. Thus, the use of a data mining program is justified, since it allows for the joint analysis of an enormous amount of information (Tseng et al., 2007).

Data mining is a computational tool that systematically searches the internet for information that cannot be obtained through conventional search engines (Kim, Suh, \& Park, 2008). For this to be possible, data miners collect, unify and organize data that have correlations or similarities (Ernst, 2003; Larose, 2014; Tseng et al., 2007), for example, in the various patent databases, making it possible to conduct studies related to technological innovations 
(França, 1997; Serafini et al, 2012; Simões et al, 2002), to patents deposited by Institutions of Implementation Higher Education (Melo et al., 2014) and to the management of the intellectual property protection system, with special emphasis on patents (Matias-Pereira, 2011), among others.

Ferraz et al. (2016) cite some examples of these miners, such as Intellixir (www.interllixir. com), Matheo Patent (www.matheo-software.com), Patent Integration (https://patent-i.com), Patent Inspiration (www.patentinspiration.com), Lens (www.lens.org/lens) and Patent2net (http:/Patent2net.vlab4u.info) - the latter two being the only ones free of charge.

\subsection{The use of Patent2net as an Open Patent Service}

The use of patents as an object of study in scientific work has gained relevance in recent years due to its importance for the development of innovations (Corrêa \& Gomes, 2013; Ferraz et al., 2016; Melo et al., 2014; Quoniam et al., 2014; Simões et al., 2002). These scientific works have contributed to the increase in the quality of postgraduate courses in Brazil which, by means of a quantitative and qualitative analysis of the content of patents, make an important contribution to society (Dantas, 2004). Such scientific relevance is only possible when one takes into account the transparency of academic research, as well as its free access to the entire community (Ferraz, Quoniam, \& Maccari, 2014).

Patent2net, a software available for Linux and Windows operating systems, functions as a patent document mining program that is available in the EPO database, called Espacenet (Carvalho, Storopoli, \& Quoniam, 2014). The main function of Patent2net is to extract the information contained in Espacenet, which in turn is the only patent database that provides access to its Application Programming Interface (API), a necessary security key for the data mining process (Mazzieri, Quoniam, \& Santos, 2016). Without this key, the mining of data allocated to Espacenet would become impossible (Ferraz, Quoniam, Pimenta, Mena-Chalco, \& Nigro, 2015). Thus, Patent2net is a tool that provides access to a large volume of patent information, in a fast and organized manner, facilitating patent document analysis (Ferraz et al., 2016; Mazzieri et al., 2016; Quoniam et al., 2014). Mazzieri, Quoniam, and Santos (2016, p. 92) state that, "the choice of Espacenet to integrate with Patent2net is due to the availability of the API provided by Espacenet - Open Patent Service," which is a large advantage, enabling free access to millions of documents.

Another advantage of Patent2net is that, by using the EPO platform, it has access to more than $110 \mathrm{~m}$ patents deposited worldwide (Arslan et al., 2006). In addition, Espacenet allows Patent2net to use its various mining functionalities, simply and without impacting the computational tool configurations.

Therefore, the use of Patent2net in an integrated manner with Espacenet is adequate so that information related to the patent filing history can be obtained on any given subject. This integration can be understood as a free OPS, which, according to Kallas (2006), is an excellent way of disseminating information for scientific research in several areas, such as civil construction (Carvalho et al., 2014), 3D printing (Reymond \& Dematraz, 2015), studies on dengue (Nigro, 2017) and DL (Storopoli, 2016).

\subsection{Distance learning}

DL is the fastest growing form of formal and informal education in the world (Bell \& Federman, 2013). In Brazil, this type of education grew by more than 110 percent, between 2014 and 2015, in terms of the availability of free courses, undergraduate and post-graduation courses, or collectively known as Institutes of Education (IE), in both private and public schools (ABED, 2015). Also, according to the ABED (2015), this growth was motivated by the level of investment that IE have to make the courses feasible, a greater volume of available technologies and access to a greater number of potential students.

This mode of teaching, which may be semi-presential or totally at a distance (Zhang, Zhao, Zhou, \& Nunamaker, 2004), has been a trend in IE for about 20 years (Hung, 2012). 
REGE 27,1

This tendency, which extends around the world, especially in Brazil, which in two years had more than 5m students enrolled in DL courses (ABED, 2015), managed to attract students who were far away from the face-to-face modality and did not have the resources to continue their studies in a traditional IE.

The DL modality has several advantages, according to Cabero (2006), such as how it allows students to learn at their own pace, the combination of different materials (auditory, visual and audiovisual), a higher level of interaction between teachers and students, flexibility of course time, among other points. However, DL courses require "technological and administrative innovation, technological infrastructure and support to the student at higher levels, when compared to the traditional face-to-face educational modality" (ABED, 2015, p. 7). Furthermore, it requires a greater faculty availability and the students do not have the same confidence in comparison with the classroom courses (Cabero, 2006). Other negative implications in DL courses can be seen in the study by Zhang, Zhao, Zhou, and Nunamaker (2004), such as the lack of quick answers to the students' questions from the teachers, lack of commitment or responsibility to the studies by the students, and potential frustration with the results obtained after the course.

Thus, although this modality of teaching is growing rapidly in Brazil and throughout the world (ABED, 2015; Hassanzadeh et al., 2012; Hung, 2012; Welsh, Wanberg, Brown, \& Simmering, 2003), it is necessary for IE to carry out an assessment of the financial return that DL courses can bring to them and to society.

\subsection{Continuing medical education in DL}

Regardless of the negative implications, DL courses still continue as a great trend and innovation in the area of education (Hung, 2012), and permeates several areas, such as the health sector (Kelly, Hopwood, Rooney, \& Boud, 2016; Oliveira, 2007; Ruiz, Mintzer, \& Leipzig, 2006), being used as a revolutionary tool within Continuing Medical Education. This new type of teaching resource allows previously practical methodologies, linked to medical and multiprofessional-medical education, to become theoretical (Govindasamy, 2002), and bring new approaches to studies related to population health (Hassanzadeh et al., 2012).

The introduction of courses in the IE health sector, using the DL methodology, contributes positively to the dialogue and to the more complete training of the medical and multiprofessional professional (Oliveira, 2007). In addition, the possibility of bringing new forms of knowledge application with Realistic Simulation techniques, practical activities with virtual simulators and the expansion of theoretical knowledge through the exchange of experiences among the health professionals of the world make the DL modality an interesting pedagogical methodology that could be applied in continuing medical education courses (Kelly et al., 2016; Ruiz et al., 2006).

Moreover, the use of DL, within the health sector, allows for the exchange of knowledge about new technologies being used in developed countries (Oliveira, 2007; Ruiz et al., 2006), which is very interesting for countries such as Brazil. Thus, the search for DL tools that provide information about new technologies (Hung, 2012), in a practical and fast manner, is relevant so that such innovations are accessible to all (Welsh et al., 2003).

The study of DL patents is essential for the expansion of knowledge about new technologies in the health sector, because it is through the study of patents that innovations can be found, especially those with cost saving potential (Bhatti, 2012; Soni \& Krishnan, 2014), that is inclusive, enabling the development of nations (Bergek et al., 2015) and technological developments in developing countries (Morescalchi et al., 2015).

\section{Research methodology}

This work presents a particularly quantitative and descriptive approach, when the indicators related to patents are described, although in some moments there are qualitative analyses with a technometric basis, when the contents of patents are evaluated. Furthermore, this work describes the way in which the computational tool Patent2net 
performs the extraction, organization and presentation of the information related to health- Implementation oriented DL patents, deposited in the Espacenet database.

The computational basis related to the operation of the application is not deeply discussed in this paper, although they can be found in the seminal work of Reymond and Quoniam (2016). Briefly, according to Ferraz et al. (2016), Patent2net executes several computational modules sequentially. For this, the user registers with Espacenet, which allows the user to access the database. Thereafter, an alphanumeric key is released that allows data mining. This alphanumeric key is the previously described API, which liberates either the free use or of a DL program payment mode of the OPS, depending on the end user requirements (Mazzieri et al, 2016).

To build the search strategy, the Thesaurus Dictionary (www.thesaurus.com) was initially used, applying the term "distance learning." The Publish or Perish computational tool (https:// harzing.com/resources/publish-or-perish) was also used to find the most cited articles in the literature, and to identify new synonyms that could contribute to the construction of the search. The identified keywords were tested one by one on the Espacenet base itself (https:// worldwide.espacenet.com/) to construct a term saturation curve, when the final string, shown in Figure 3 (at the top), was then established. After the extraction of the patent documents, which is based on a search strategy containing all the terms related to the subject of interest, Patent2net organizes the information and displays the patents, allowing for a very dynamic analysis, based on several indicators provided by the analysis interface itself, such as the interaction networks among inventors, inventors' countries and other forms of evaluation that will be presented as a result of this work. More details of computational order can also be obtained in its entirety in recent doctoral thesis defended by Mazieri (2016).

In the Description and Analysis of Results section, the screens provided by the tool will be presented, which will allow any researcher to access the available results on DL patent documents. By becoming familiar with the features of the tool, other researchers will be able to use this section as a guide to access patent documents on various subjects, obtaining the desired information in a fast and organized manner.

\section{Description and analysis of results}

Figure 1 shows the initial screen available on the web with a series of results from the up to date patent analysis provided in this paper. Among the main subjects evaluated are 3D Printing, Entrepreneurship, Big Data, Dengue, DL, among others. To access any of the aforementioned subjects, it is necessary to click on the link in Figure 1, and select the subject. After that, the researcher will be directed to the screen shown in Figures 2 and 3, which pertain to the DL patent, which is the central focus of this work.

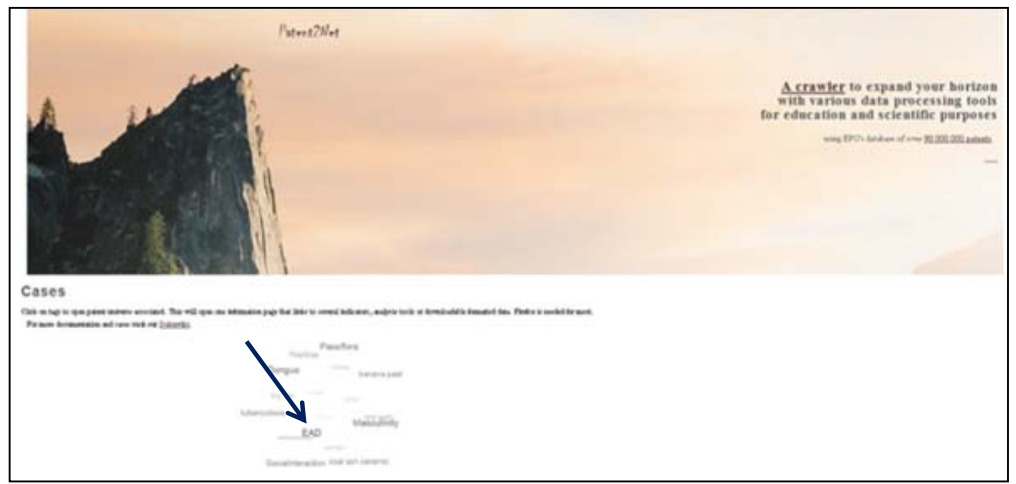

Source: http://Patent2netv2.vlab4u.info/index.html

Figure 1. Access screen to the results provided by Patent2net, in which the researcher can search the subject of interest for patent analysis 


\section{REGE 27,1}

\section{4}

Figure 2.

Screen with links to patent analysis in DL available for consultation by researchers
Figure 3.

Screen showing how to search for subjects related to the topic DL patents

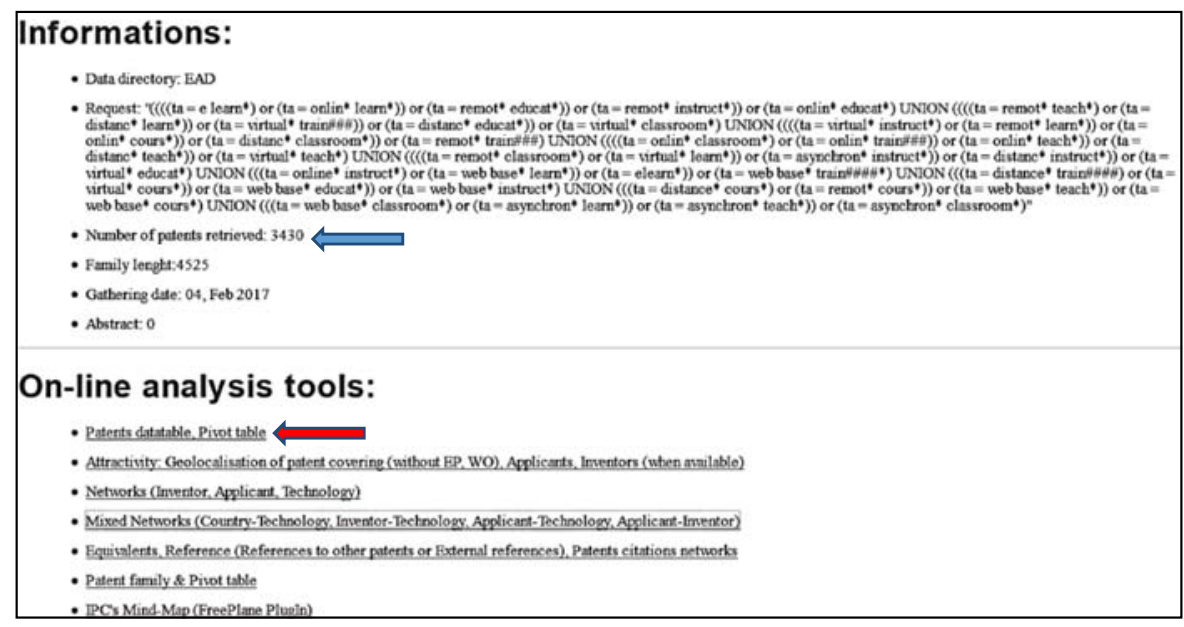

Source: http://Patent2netv2.vlab4u.info/DONNEES/Eadv4.html

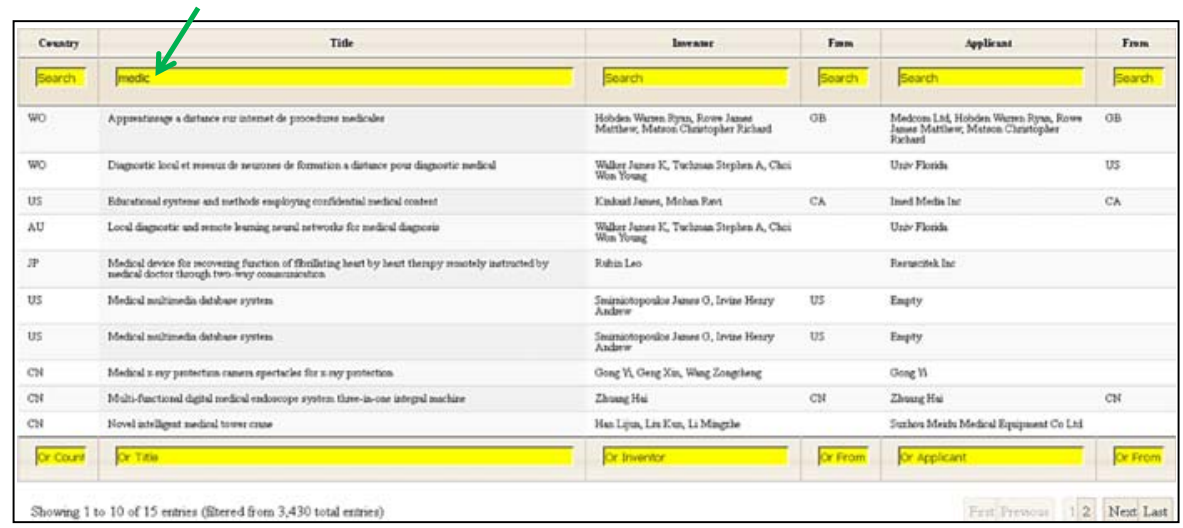

Source: http://Patent2netv2.vlab4u.info/DONNEES/Eadv4/Eadv4CartoInventor.html

Figure 2 shows the screen with the links for analysis of a series of indicators related to the DL patents available for consultation, and Figure 3 shows the screen for filtering and searching for patent information on the subject. Then you can check the item "Information," which has the search strategy (keyword sequence and search codes) used by Patent2net to locate the patents on the subject desired in Espacenet. Below, in the item "On-line analysis tools," there is a second link to the geographical map of the countries where the patent was deposited, the inventors and the countries that invested in the DL patents. Figures $4-6$ show the query interface of the patent documents by means of some indicators. Figures 7 and 8 instruct the user how to generate dynamic tables that allow for several analyses, presented later in Figures 9-12. Below, on the third and fourth links, the researcher can have access to the connection networks involving inventors, countries and companies related to patents on the subject of DL, shown in Figures 12-16.

In the upper part of Figure 2, in the item "Information," the number of patents extracted from Espacenet (blue arrow) is identified, totaling 3,430 documents involving the theme 


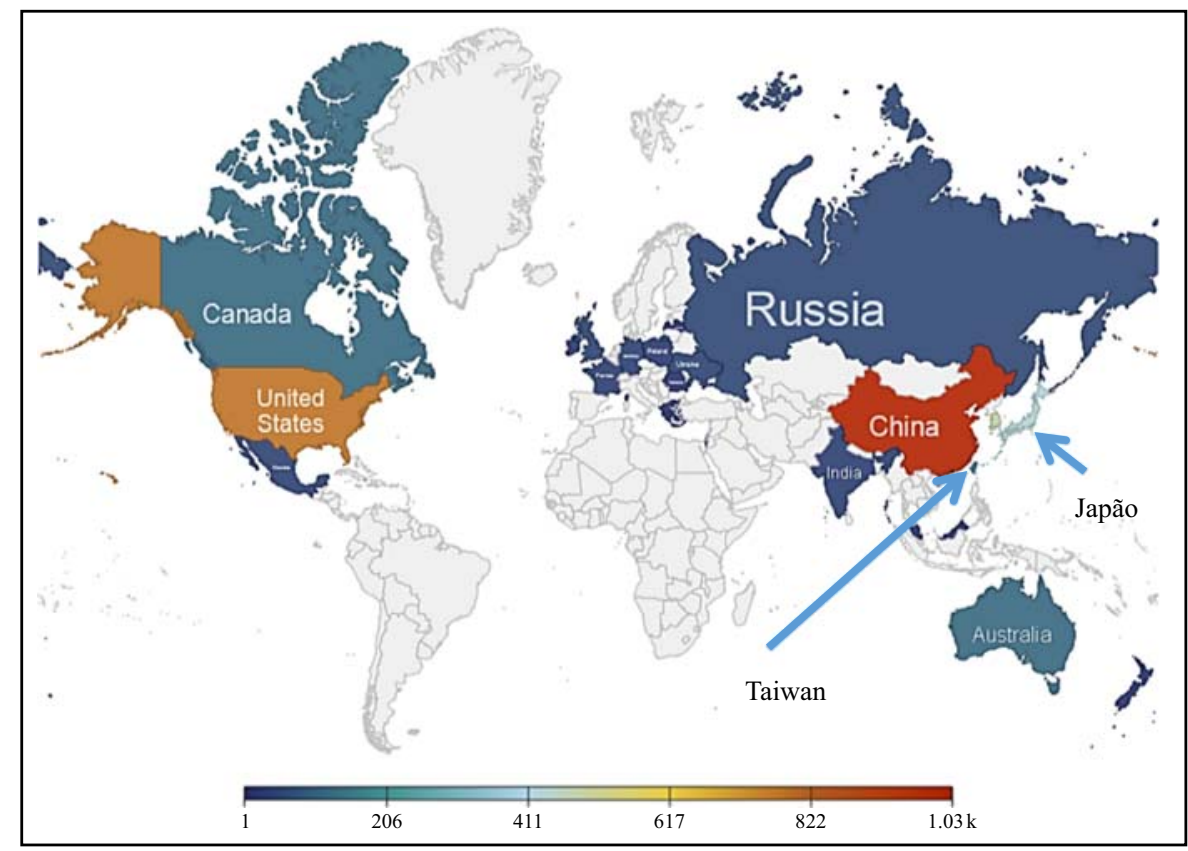

Source: http://Patent2netv2.vlab4u.info/DONNEES/Eadv4/Eadv4Carto.html

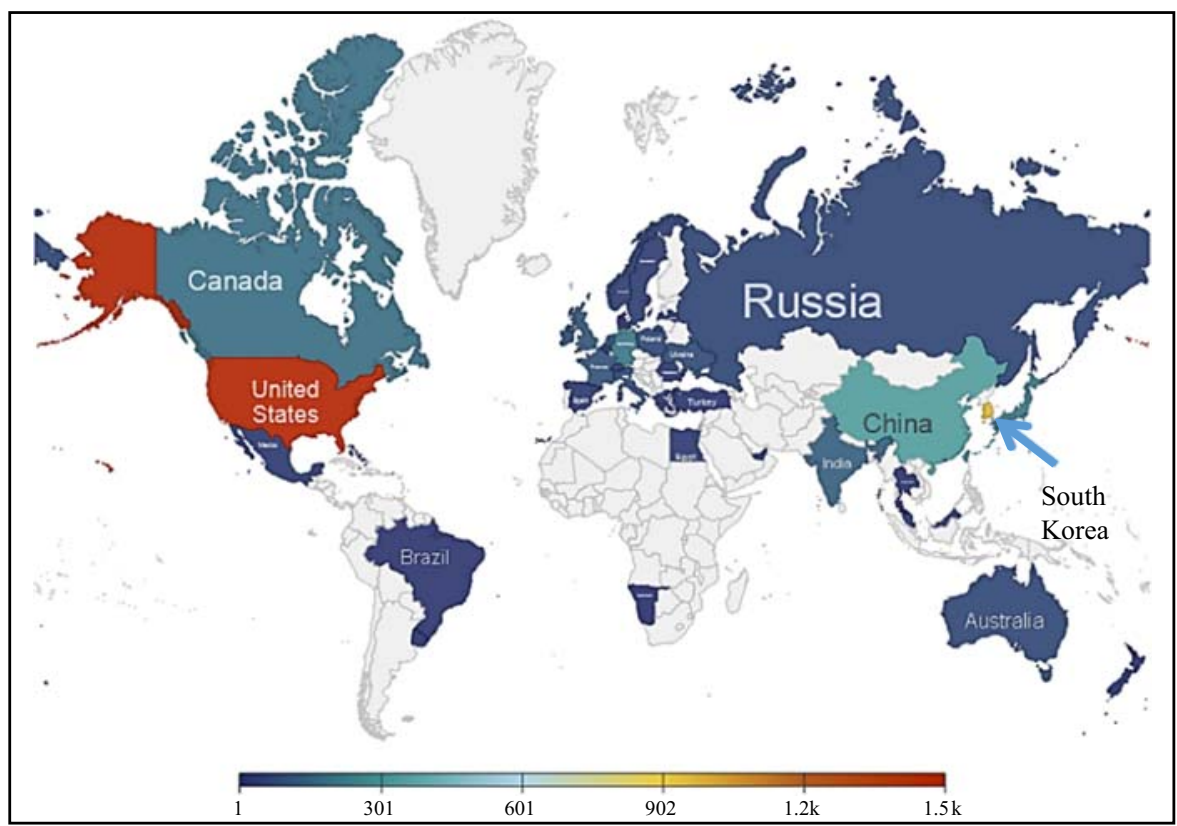

Source: http://Patent2netv2.vlab4u.info/DONNEES/Eadv4/Eadv4CartoInventor.html
Implementation of a DL program 45

Figure 4.

Map of the countries where the DL patents were deposited

Figure 5.

Geographical map of countries with inventors of deposited DL patents 
REGE

27,1

46

Figure 6.

Geographical map of the countries of the companies that invested in the deposited DL

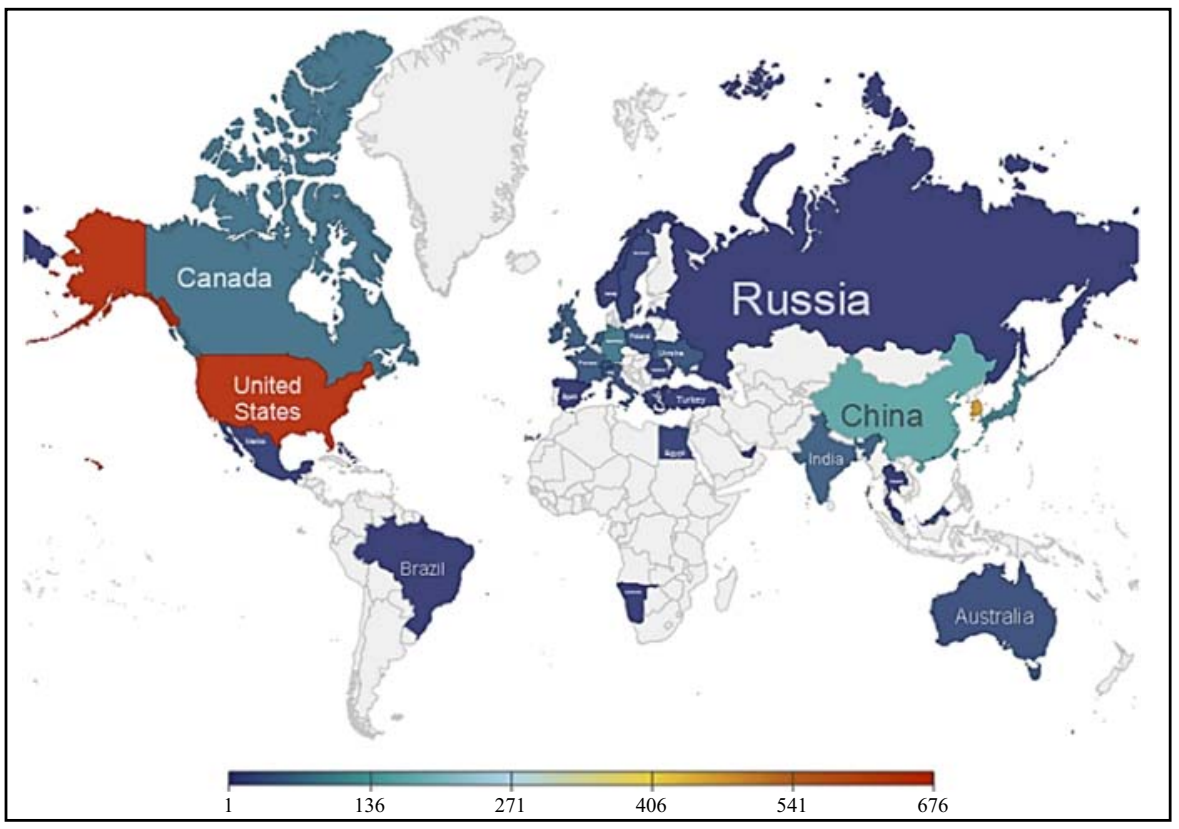

Source: http://Patent2netv2.vlab4u.info/DATA/EAD/EADCartoApplicant.html
Figure 7.

Screen with the number of patents deposited in DL

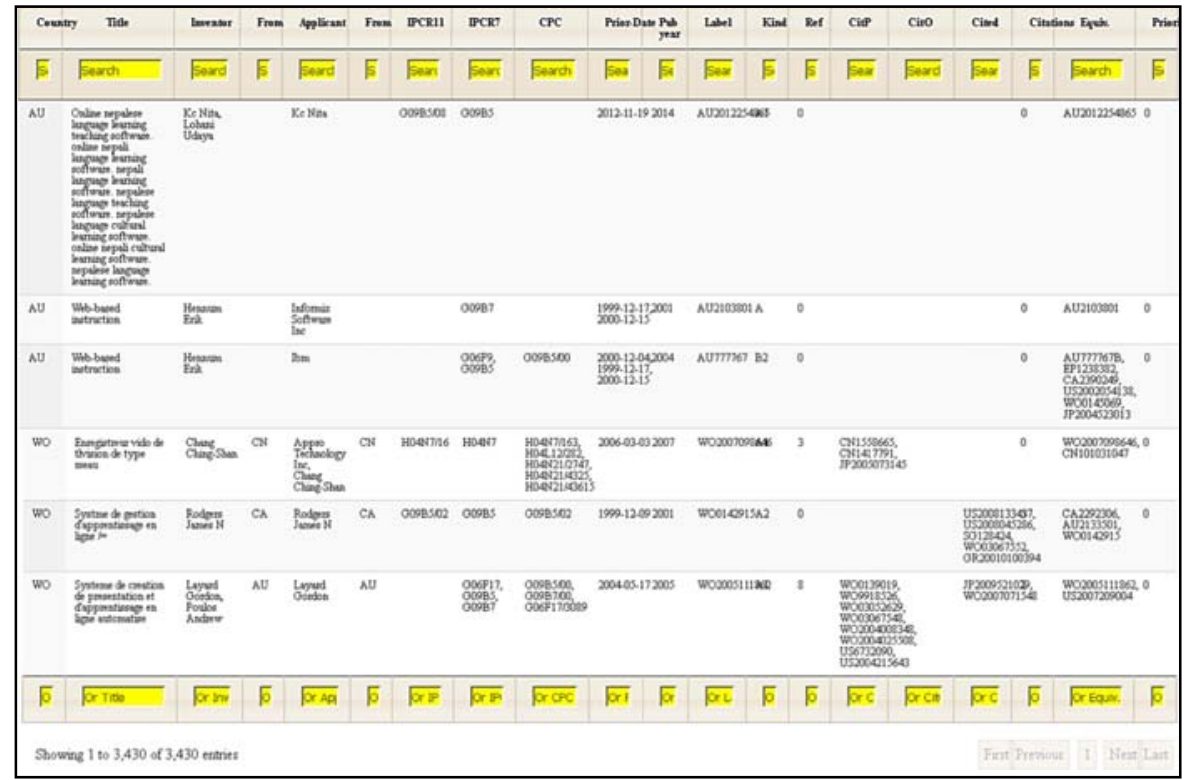

Source: http://Patent2netv2.vlab4u.info/DONNEES/Eadv4/Eadv4.html 


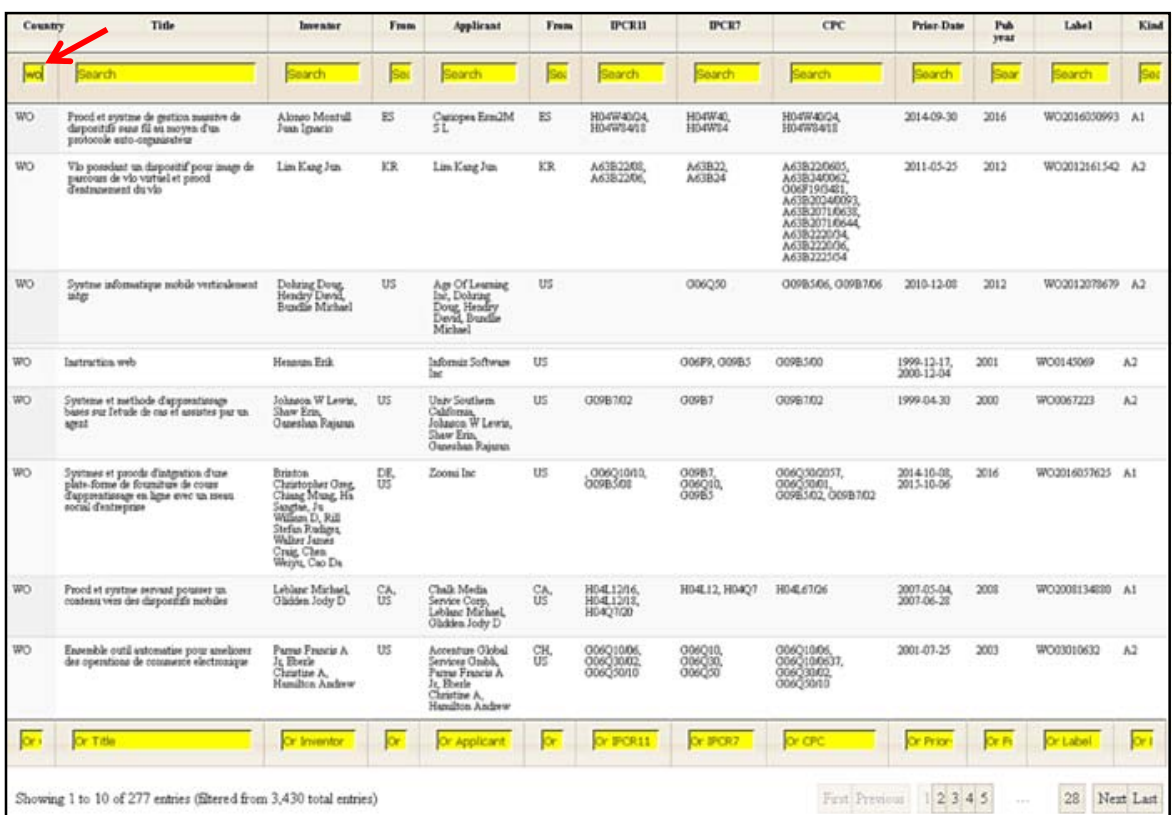

Source: http://Patent2netv2.vlab4u.info/DONNEES/Eadv4/Eadv4.html

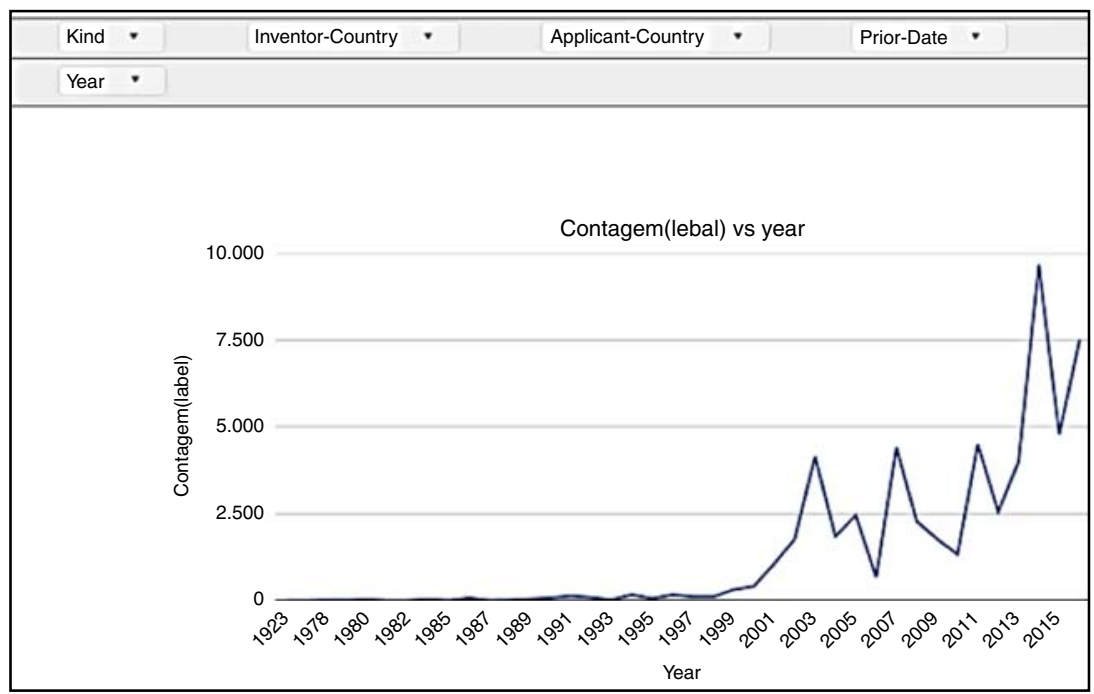

Source: http://Patent2netv2.vlab4u.info/DONNEES/Eadv4/Eadv4Pivot.html

DL, deposited in the up to date database for extraction of the information. By clicking on the first link in the "On-line analysis tools" item (red arrow), you will have access to a new screen, shown in Figure 3, where you can enter keywords in the search fields and filter specific subjects, within the DL theme. In order to demonstrate the usefulness of this
Implementation of a DL program

Figure 8.

Screen with the number of patents

deposited with worldwide protection (acronym "WO") by means of the "Country"

Figure 9. Line graph with the chronological evolution DL patent document deposition 


\section{REGE 27,1}

\section{8}

\section{Figure 10.}

Tree graph indicating the place of protection of the DL patent documents, according to the classification

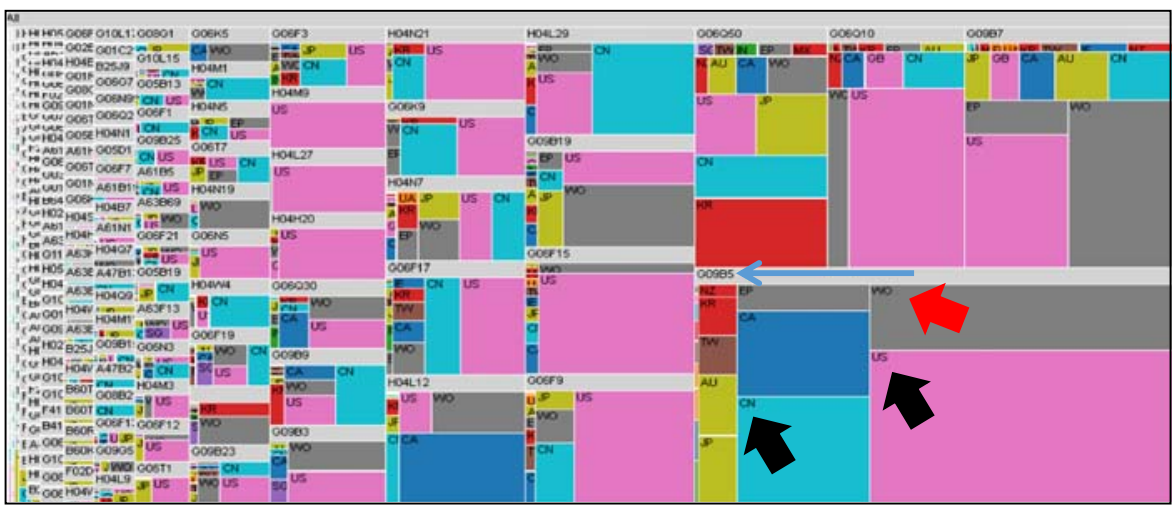

Source: http://Patent2netv2.vlab4u.info/DONNEES/Eadv4/Eadv4Pivot.html

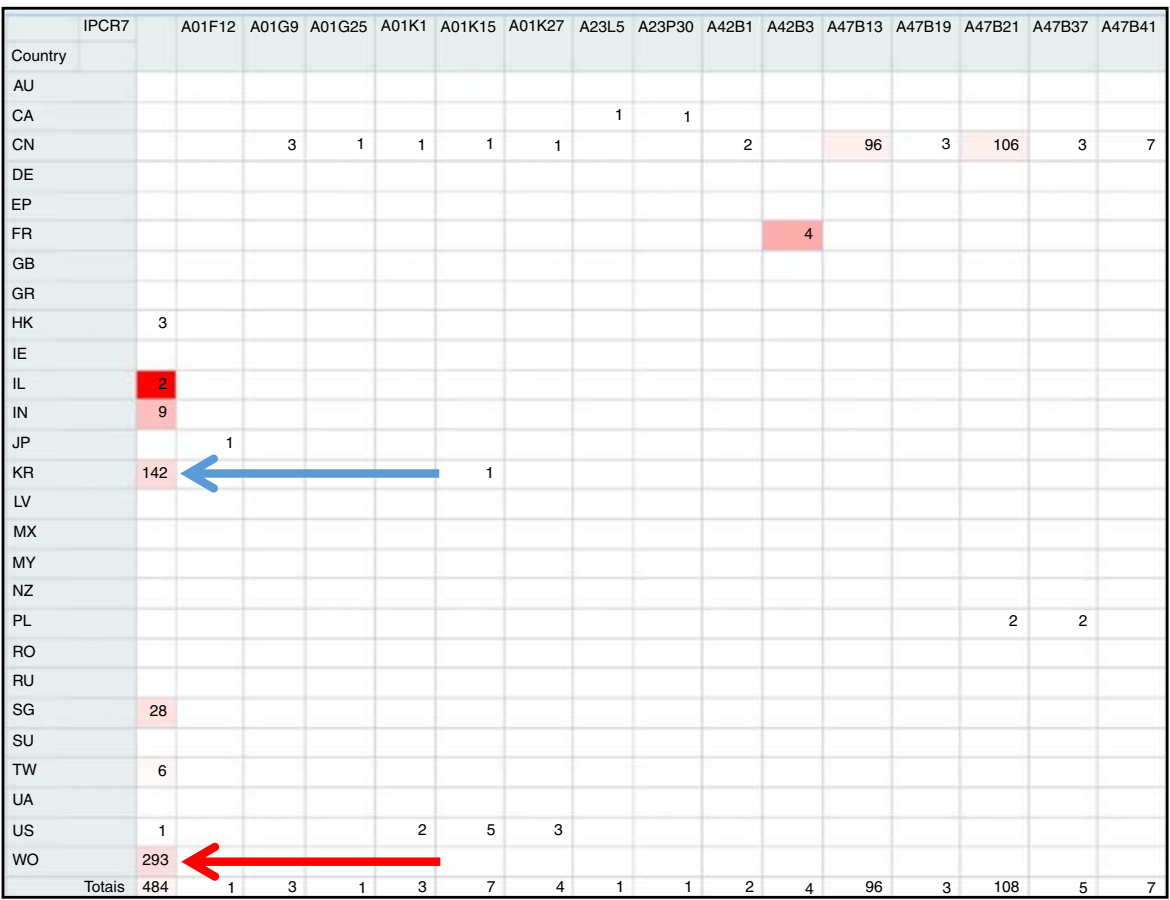

Source: http://Patent2netv2.vlab4u.info/DONNEES/Eadv4/Eadv4Pivot.html
Figure 11.

Screen with a heat map that demonstrates the relationship between the deposit country and the technology (using IPCR7), based on the DL patents screen, the term "medic" (green arrow) was inserted in the "title" field, a term related to the central focus of this work, which is to present DL patents linked to continuing medical education. This topic is of special interest to the authors of the paper, who work in the implementation of DL undergraduate courses, especially nursing courses, as well as specialization courses for physicians. As a result, 15 patents related to the topic "continued medical education" were selected, from the 3,430 on DL patents available in Espacenet. 


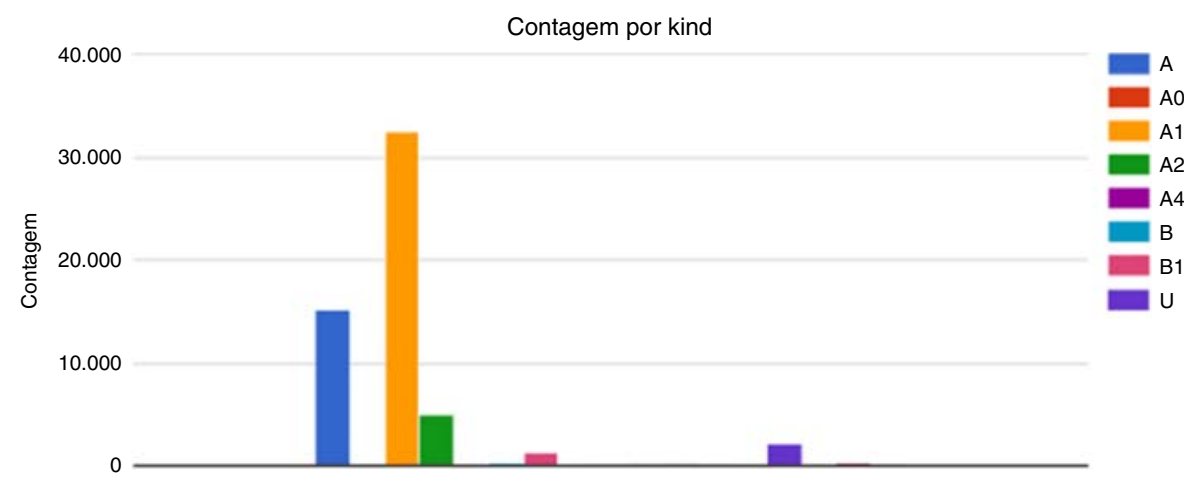

Source: http://Patent2netv2.vlab4u.info/DONNEES/Eadv4/Eadv4Pivot.html

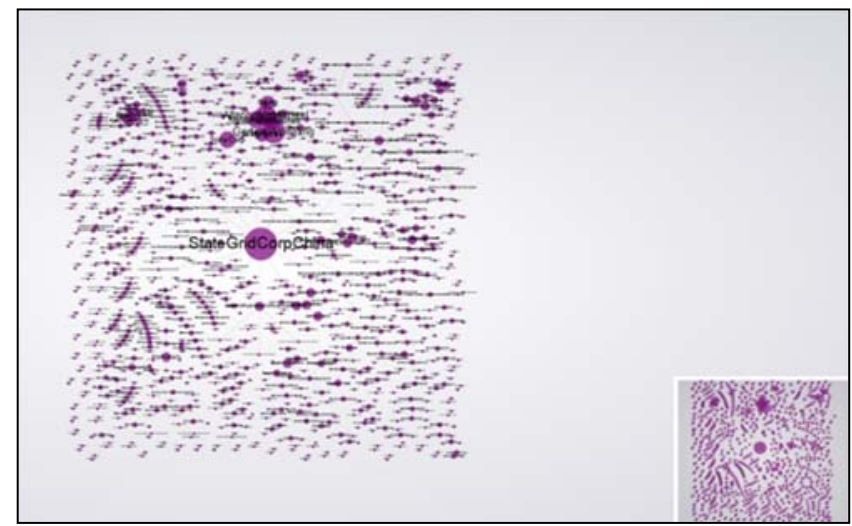

Source: http://Patent2netv2.vlab4u.info/DONNEES/Eadv4/GephiFiles /Eadv4_ApplicantsJS.html
Implementation of a DL program

Figure 12.

Screen a bar graph demonstrating the legal status of DL patents deposited
Figure 13.

Screen showing the network of relationships between the companies that invested in deposited DL patents

Figure 4 shows the geographical map of the countries where the 3,430 total DL patents were deposited, and where protection of the patented technology was sought. In this figure, it is shown, based on coloration, that China with 1,030 patents deposited, 34 percent of the total, is the country that deposited the highest number of DL patents, followed by the USA, with 779 documents, 26 percent, Japan with 488 patents, 16 percent and Taiwan with 88 patents, about 3 percent of the total. The other 1,088 patents deposited, which represents about 36 percent of the total, are divided among the 14 remaining countries and are presented on the map. It is inferred that due to patent filing policies in China are more flexible, permitting the dissemination of technology over the rights of inventors (Sun, 2003), the preference for being the main country of deposit is the most practiced. This practice, promoted in China, is totally different from that in Brazil, since the management of the Brazilian intellectual property protection system, especially with patents, is inconsistent (Matias-Pereira, 2011). This lack of attention to the intellectual protection of patent documents in Brazil can be considered a competitive advantage (Teixeira \& Souza, 2013), since unpatented patents become automatically free for replication, allowing the use of the technologies present in any patents, except those with worldwide protection.

Figure 5 shows the map countries with inventors who deposited patents. It is noted that the USA has 1,500 inventors, 44 percent of the total, and South Korea has 950 inventors, about 


\section{REGE 27,1}

\section{0}

Figure 14.

Screen showing the mixed network between the inventors and the technologies present in the deposited DL patents

Figure 15.

Screen showing mixed networks between companies and the technologies present in the deposited DL patents

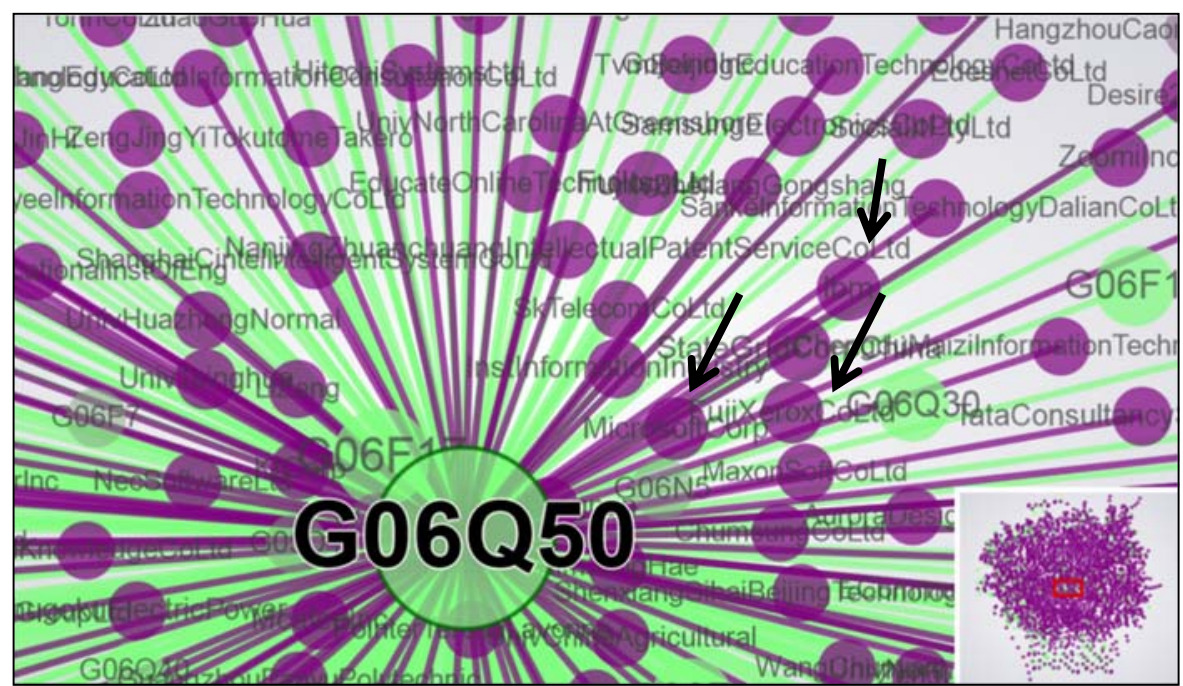

Source: http://Patent2netv2.vlab4u.info/DONNEES/Eadv4/GephiFiles/Eadv4_CrossTechJS.html

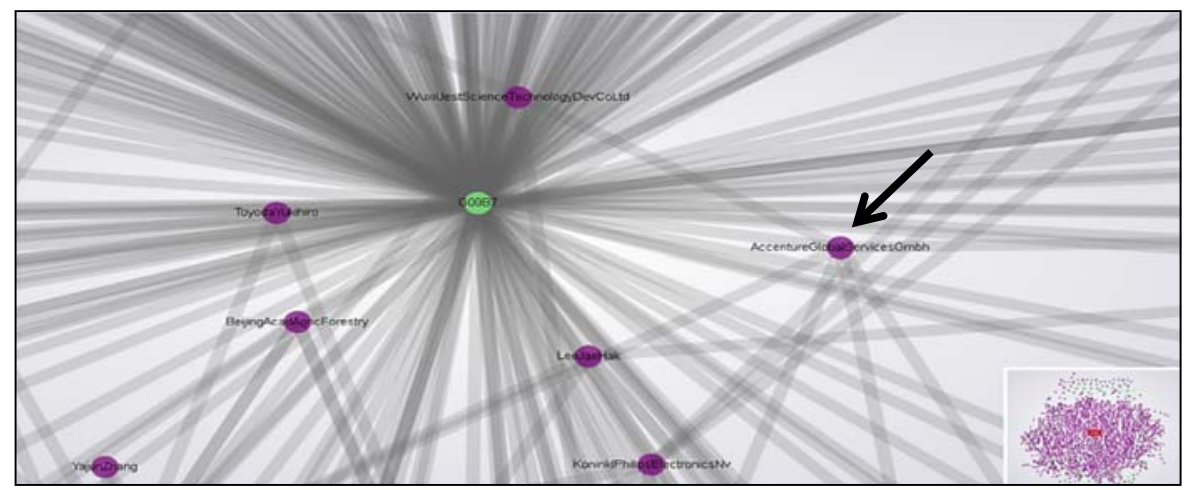

Source: http://Patent2netv2.vlab4u.info/DONNEES/Eadv4/GephiFiles/Eadv4_CrossTechJS.html

30 percent, which reinforces that in most cases inventors are not from the country where the patents are deposited (Sun, 2003). It is also noteworthy that there is little participation from Brazil, which only has two inventors, ahead of countries like Namibia, which only has one inventor. This situation proves that investments and incentives to technology research in Brazil have been almost non-existent over the last decade (Gartner, Zwicker, \& Rödder, 2009). In addition, Choi and Heinemann (2016) show in their study that countries that are more economically developed make more investments in technology. Thus, it is understood that the insignificant participation of Brazilian inventors in the development of DL-oriented technologies is probably due to the low financial incentive for this type of research.

Figure 6 shows the geographical map of the countries with companies that invested in the DL patents. It can be seen that the countries with the largest number of companies are the USA, with 676, about 20 percent, and South Korea with 469, 14 percent, followed by China, with 157, 4.5 percent of the total. This allows us to infer that there is a strong relationship 


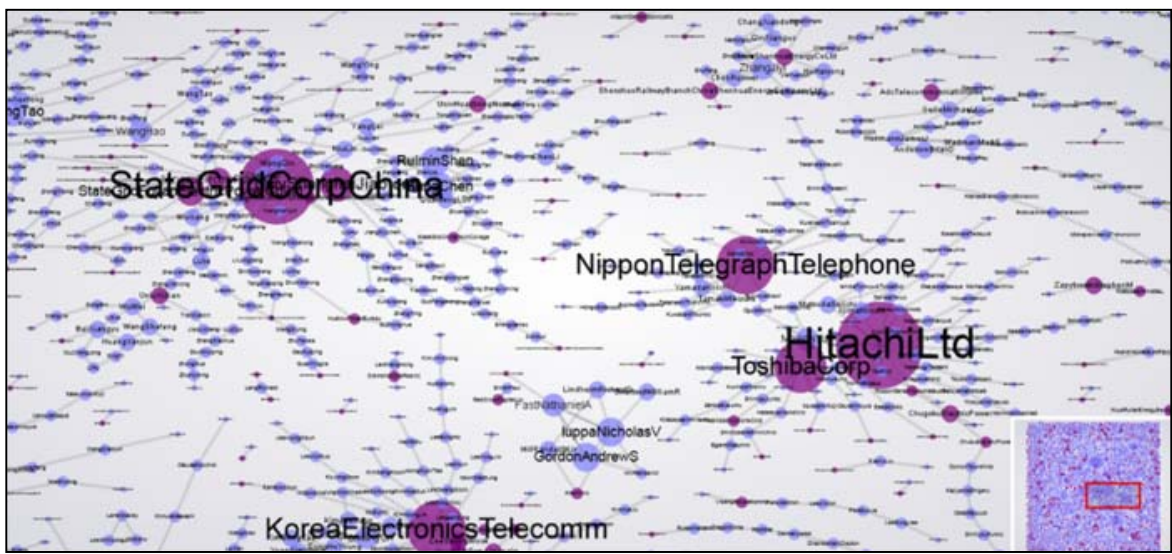

Source: http://Patent2netv2.vlab4u.info/DONNEES/Eadv4/GephiFiles/Eadv4_CrossTechJS.html
Implementation of a DL program

Figure 16.

Screen showing mixed networks between inventors and the companies that deposited DL patents

between the countries of origin of the inventors, as shown in Figure 5 , and the countries of the companies investing in DL technologies (i.e. USA and South Korea). Again what is presented here reinforces what is presented in the study by Choi and Heinemann (2016), which links the economic development of nations and investment in new technologies. In fact, Brazil has only one applicant for a DL patent, thus emphasizing the fact that investments in innovation in Brazil remain incipient (Hoffmann, Coral, \& Jara, 2014).

Figure 7 demonstrates that the Patent2net interface can query patent documents using criteria, such as the name of the inventor, words in the patent title, the code of the technology and the code related to the type of patent, among others. Through the screen in the upper left corner, the researcher can select one of the 3,430 DL patents available on the platform, inserting the initials of the countries with patent inventors, or even the world classification code of these patents (IPCR 7 or IPCR 11), for example.

Figure 8 shows one of the possible document selections that can be made through the interface in question. To do this, the "WO" (red arrow), which identifies patents with worldwide protection, was inserted in the "Country" field in the upper left corner of the screen. By means of this selection, the researcher can consult all the DL patents with worldwide protection, which therefore cannot be reproduced in his country if they are still in the aforementioned concession period. It is also possible to refine the search with the insertion of new filters in the other fields.

Figure 9 can be accessed by clicking on the link Patents datatable, Pivot table, in the item "On-line analysis tools." This function allows the researcher to identify the evolution of the DL patent documents. After accessing the link, it is necessary to access the second tab automatically generated by the interface, named Patent bibliographic data, in which there is a line graph showing the years in which the documents were deposited. This feature allows the researcher to follow the evolution in the number of DL patents deposited between the years of 1923 and 2015.

This figure shows that the first peak appears in the year 2000 and remained stable until 2010, which is supported by the study of Hung (2012) as the main period of innovations and inventions of new DL technologies. After this, between 2011 and 2014, there was a new peak in the number of DL patents due to the increase in the supply of IE courses (ABED, 2015; Bell \& Federman, 2013), totaling 3,430 documents in 2015.

In Figure 10, which is also accessed by the link Patents datatable, Pivot table, in the second tab (Patent bibliographic data), a "tree chart" shows which countries requested the 
REGE 27,1

protection of which technologies, based on the seven-digit international classification code. For this, the "IPCR7" and "Country" indicators have been inserted along the "X" axis. An example of this figure analysis is the G09B5 technology, which refers to patents used for teaching on electronic devices. This technology is most protected in the USA, with 250 documents, 31 percent, and China, with 100 patents, 12.5 percent of the total (black arrows). Further analysis of this figure demonstrates that 120 patent documents, 15 percent of the total, have worldwide protection (acronym WO indicated with the red arrow).

Figure 11 shows the relationship between the deposit country and the technology (also using IPCR7), based on the DL patents in the form of a heat map. There are 142 technologies with protection in South Korea (blue arrow), which are only behind the technologies with worldwide protection, represented by the acronym WO, totaling 293 (red arrow). Furthermore, Brazil is one of the countries that has not filed a DL patent, which reinforces the results of Hoffmann, Coral and Jara (2014), who identified Brazil as a nation that does not invest in technological research, and as a country that does not have mechanisms to protect the innovations developed by its companies.

Finally, Figure 12 shows, by means of a bar graph, the distribution of DL patents according to their legal status. Notice that the patents receive several qualifications (in this example, the classification goes from A to U), which refer to a list of Internationally agreed Numbers for the Identification of Data codes (INPI, 2017).

In this figure, patents with A classification (51 percent) stand out, totaling 1,741 documents, which refer to patents granted with protection in the country in which they were deposited, and A1 (30 percent), which represent 1,046 documents, which are patents granted with global protection (WIPO, 2016). Following, there are patents with A2 (6 percent), totaling 194 documents, which are patent documents issued after the first publication, with international application and exclusive protection to the country in which it was deposited, and B1 (5 percent), with 163 documents, which are patents that needed changes and were republished for final approval (Thomson, 2017).

Finally, in the analysis of Figure 12, there are patents with a U rating (8 percent), 286 in total, which define the documents related to utility model patents (Thomson, 2017) and that do not have worldwide protection (WIPO, 2016). Without this protection, these patents are inclusive and of lower cost for reproduction, and have cost saving potential (Bhatti, 2012; Soni \& Krishnan, 2014).

Thus, the technologies described in this patent can contribute to the increase of technological competitiveness in countries such as Brazil, with low investment in innovation (Teixeira \& Souza, 2013), and can be replicated and adapted to fit their needs.

Other possibilities exist for the analysis of information on DL patents, which is shown in Figures 13-16 and illustrates network relationships between companies that invested in the deposited patents (Figure 13), mixed networks between inventors and the technologies present in the patents deposited (Figure 14), mixed networks between companies and the technologies present in the patents deposited (Figure 15) and mixed networks between inventors and the companies that invest in deposited DL patents (Figure 16).

In Figure 13, it is possible to see the network of companies that invested in deposited DL patents. Standing out is the company "State Grid Corp" of China, which is one of the largest distributors of electricity in the world. The presence of this company, as the largest, confirms the information already presented in Figure 4, which shows that China is the main country filing DL patents. In addition, the main relationships with other organizations occur with technology companies, such as "Sony Corp" and "SAP AG," which allows us to infer that the relationships are complementary in the development of technological tools aimed at DL.

Still analyzing Figure 13, the relationship between "State Grid Corp China" and the inventors of DL technologies are highlighted. It should be pointed out that the main relationship occurs with the German inventor "Gerteis Wolfang," the holder of 17 patents. 
This leads to the realization that large corporations are actively pursuing innovations around the world, not just in their home countries, thus expanding coverage and investing in new technologies.

Figure 14 shows that the main technology present in the relationship with mixed networks related to deposited DL patents is G06Q50. This technology refers to systems or methods specially tailored for a specific business sector (CPC, 2017), and is related to companies like "IBM," with 311 deposited DL patents, "Xerox Co. Ltd" with 107 patents, and "Microsoft" with 397 patents. This relationship allows us to understand that companies developing e-learning software, such as those highlighted in Figure 14, are related to patent technology adapted to a specific business sector.

Figure 15 shows G09B7 technology, which is related to electronically operated teaching devices or devices with questions and answers (PatBase, 2017). The relationship between G09B7 technology and the company "Accenture Global Service Gmbh" is highlighted in the figure, since it has $20 \mathrm{DL}$ patents deposited, all of which are related to teaching devices that aid in managerial decisions.

Figure 16 shows the relationship between the inventors and the companies that invest in deposited DL patents. This figure, again, shows the presence the "State Grid Corp. China" as the main company, which already justifies its presence as the largest company related to DL patents, as shown in Figure 13. It is also confirmed, in the same figure, that this company is the one with the largest number of relationships with inventors, 57 in total, which explains its prominent position in the network, and allows us to infer that it is an organization that invests highly in development and supports several inventors in the sector.

To conclude the Results section, Figures 17-22 are presented to demonstrate how a DL patent can be utilized specifically in the health sector. It was chosen to present, in the Figures, a patent that highlights the use of the methodology for continuing medical education, linked to

\begin{tabular}{|c|c|c|c|c|c|c|c|c|c|c|}
\hline Crovery & nim & limentar & Finm & Antiknat & ITCRII & INCE & $\operatorname{man} \operatorname{mat}$ & m & 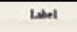 & Kind \\
\hline$\sqrt{\text { eas }}$ & hlownng & Earch & $\sqrt{\text { ees }}$ & Beanon & Eaxo & Beran & Eexch & Foxd & Bexch & Feas \\
\hline Tw & 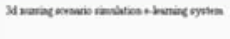 & 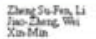 & $\mathrm{Tw}$ & 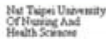 & & oosen & $20 \cos x$ & mit & 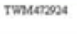 & v \\
\hline
\end{tabular}

Source: http://Patent2netv2.vlab4u.info/DONNEES/Eadv4/Eadv4.html
Implementation of a DL program

Figure 17. Screen with the filter inside the tool Patent2net, which filters DL patents focused on the medical area

Figure 18.

Espacenet screen that allowed the search of the selected patent in Figure 17

Source: https://worldwide.Espacenet.com 


\section{REGE 27,1}

\section{4}

Figure 19.

Presentation of the patent previously selected and the items for consultation on the left side
Figure 20.

Screen with the previously selected patent document

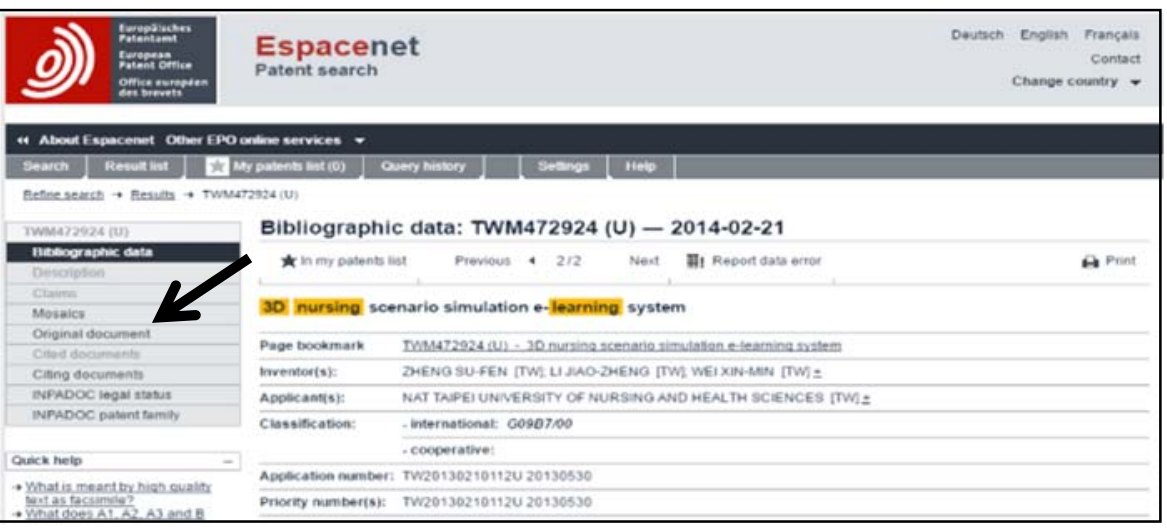

Source: https://worldwide.Espacenet.com/

（19）中华人民共和国国家如识产投局

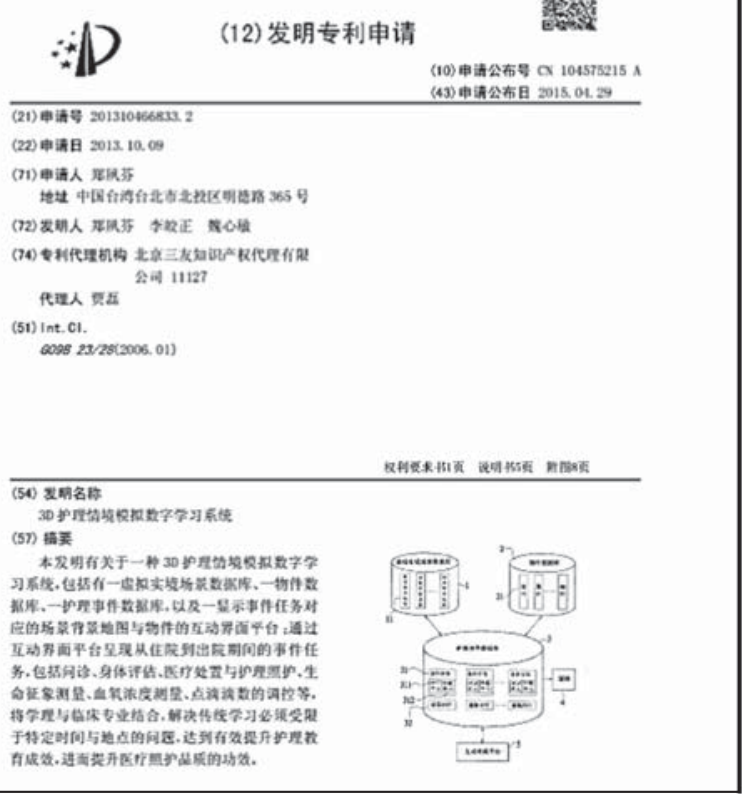

Source: https://worldwide.Espacenet.com/

the use of 3D simulation technologies, which according to Landmann, Havron, Patel, Thompson, and Lees (2016) is the area that contributes in practice to the improvement of continuing medical education, since it is a format that is closer to the current reality of health professionals. Thus, in Figure 17, the filter used in the main interface generated by Patent2net is searched for DL patents with a medical focus. In Figures 18 and 19, it is possible to see that the Espacenet platform makes it possible to search for the previously selected patent, in 


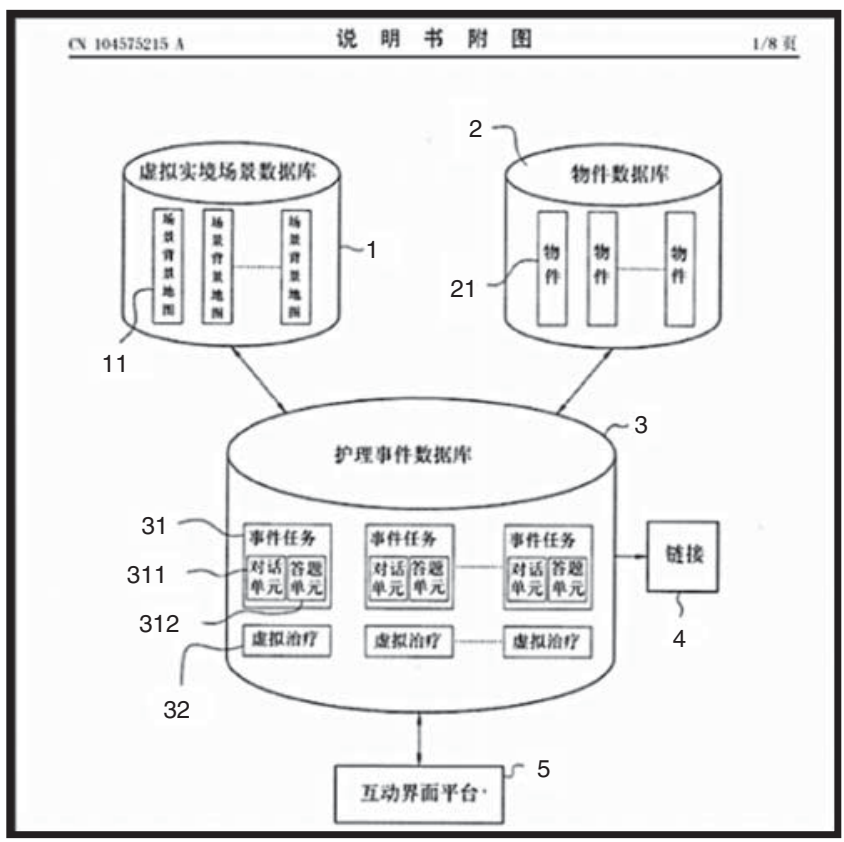

Implementation of a DL program

Source: https://worldwide.Espacenet.com/

Figure 21

Demonstration of the digital learning system of situational simulation of nursing

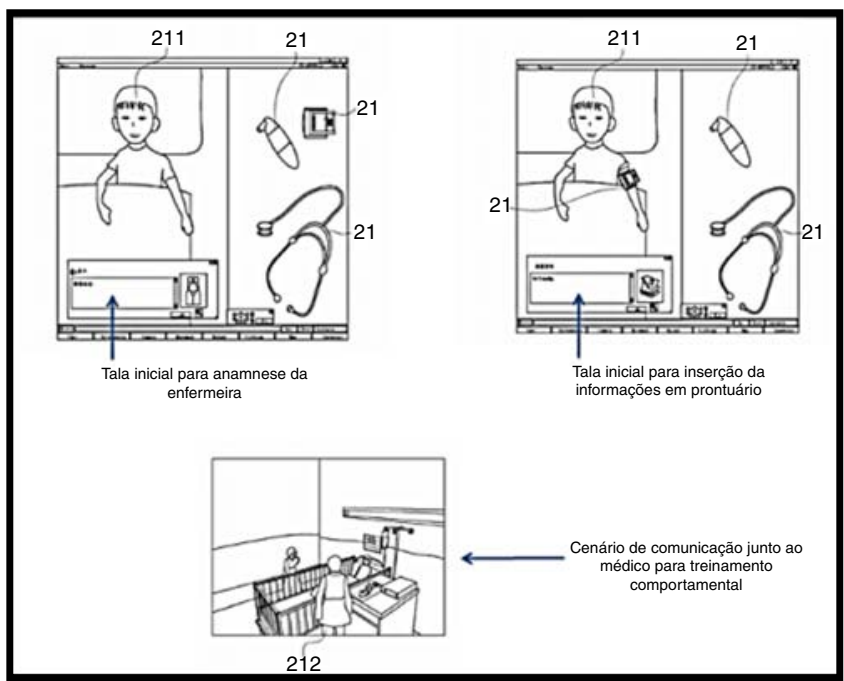

Source: https://worldwide.Espacenet.com/

Figure 22.

Presentation of some tasks of the 3D digital simulation system for nursing learning

Figure 17, for the interested party to consult integrally. Figure 20 shows the screen with the patent document previously selected for analysis. Finally, Figure 21 demonstrates the digital learning system of situational simulation of nursing and in Figure 22, screens are presented with some tasks of the 3D digital simulation system for nursing learning. 
REGE 27,1

Figure 20 shows the screen with the first page of the original patent document, filed by the Chinese inventor "Zheng Sufen." This patent refers to a 3D digital situational simulation nursing learning system.

Figure 21 shows the digital situational simulation nursing learning system described in the patent, which comprises a virtual reality database (items 1 and 11), a database of objects (items 2 and 21), a nursing events database (item 3) and an interactive interface platform to display scene background maps (items $31,32,311$ and 312), and objects corresponding to the event tasks (items 4 and 5).

In Figure 22, some tasks provided, to the student, by the 3D digital simulation system for nursing learning are presented, including: anamnesis done by a nurse, insertion of information in a patient's chart or a scenario of communication with the physician for behavioral training. This is exhibited through the interactive interface platform, which combines theories and clinical practice.

This system solves the limitations of adequate time availability for the traditional and classic training of the nurses. Thus, corroborating the study by Kelly, Hopwood, Rooney, and Boud (2016), which showed that the effect of nursing education is improved effectively and may reflect positively on the quality of the nursing service itself.

\section{Conclusions}

This paper presents the tools and platforms available for fast and efficient extraction, organization and presentation of patent information, and highlights the organization and presentation of data made by Patent2net based on Espacenet, which discovered patent documents in DL, focused on Continuing Medical Education.

The results presented in this paper demonstrate how the Patent2net computational tool can increase the dissemination of knowledge by extracting and organizing data from millions of patent documents, in a direct and user-friendly manner. Through this analysis, in which the utility of this computational tool was justified, it is possible to note the social responsibility of the present research, since it presents to the scientific community a free tool that allows access to the technologies, previously ignored, to any interested party, for the promotion of economic, technological and social development.

Corroborating with the results of this research and with its contribution to the academic and scientific community, in this study a patent was presented for continuing medical education focused on teaching technologies with the use of 3D simulation, which is an area health training lacks (Landmann, Havron, Patel, Thompson, \& Lees, 2016). This Taiwanese patent does not have extended protection in Brazil, based on international patent law, and can be freely replicated in the country without the need for any rights payments, meeting all legal requirements governing the subject of industrial and intellectual property.

Among the limitations presented in this work are the use of a single patent database, Espacenet, for the presentation of the results. This has restricted the demonstration of other search platforms which, although they have a lower patent volume compared to the more than $110 \mathrm{~m}$ documents available at Espacenet, could broaden the focus of this work. In addition, only one subject was selected, DL, in order to demonstrate the operation and applicability of the Patent2net tool.

The selected patent documents pertaining to the innovation of a nursing training system using simulated 3D scenarios, in which real situations of the professional's daily life are developed, with the aid of the system, so that the nurse can be updated on practical, technical and behavioral issues. This form of training, according to Zendejas, Brydges, Wang, and Cook (2013), makes nurses' training more flexible at the beginning of their careers, and promotes a continuous updating from professionals with more experience. Through this model of continuing medical education, in which an innovation is added to the teaching of health professionals, the community as a whole benefits from better prepared 
professionals (Kelly et al., 2016), which should lead to a drastic reduction of professional Implementation errors in the healthcare field (Landmann et al., 2016).

Finally, in relation to the subject of this research, the importance of future studies that involve DL patents focused on continuing medical education is highlighted, which is a sector that needs new methodologies to improve practices and processes (Landmann et al., 2016). Future studies on other tools and platforms for extraction, organization and presentation of patent data are recommended, which would allow for a deeper understanding of the subject and the differentiation by researchers of what procedures to follow, according to their goals.

It is noteworthy that patent mining with Paten2net software can be applied in the search for solutions to the most different problems, including in the social sphere. The present experiment presented a feasible solution to a business as well as governmental problem related to the training of professionals in remote regions. However, nations with little investment in Science and Technology, such as Brazil, may use the methodology presented to solve, for example, problems of basic sanitation, food distribution and reuse, neglected diseases, public safety, among others. In short, patents are technical documents with free solutions to numerous problems, currently little explored, and in view of this fact, it is understood that the culture of seeking solutions in patent documents should be encouraged at the national level.

\section{References}

ABED (2015). Censo EAD. BR: Relatório analitico da aprendizagem a distância no Brasil 2014. Rio de Janeiro: Associação Brasileira de Educação a Distância. Available from: http://bibliotecadigital. fgv.br/dspace/handle/10438/17079

Aoki, R., \& Schiff, A. (2008). Promoting access to intellectual property: Patent pools, copyright collectives, and clearinghouses. R\&D Management, 38(2), 189-204.

Arslan, T., Haridas, N., Yang, E., Erdogan, A. T., Barton, N., Walton, A. J., \& Howells, W. G. J. (2006). Espacenet: a framework of evolvable and reconfigurable sensor networks for aerospace; based monitoring and diagnostics. AHS (pp. 323-329). Istanbul: IEEE. Available from: https://doi.org/ 10.1109/AHS.2006.34

Barbieri, J. C., \& Álvares, A. C. T. (2005). Estratégia de Patenteamento e Licenciamento de Tecnologia: conceitos e estudo de caso. Recuperado 1o de fevereiro de 2017. Available from: www.redalyc. org/articulo.oa?id=94771708 (1o. de fevereiro de 2017).

Bell, B. S., \& Federman, J. E. (2013). E-learning in postsecondary education. The Future of Children, 23(1), 165-185.

Bergek, A., Hekkert, M., Jacobsson, S., Markard, J., Sandén, B., \& Truffer, B. (2015). Technological innovation systems in contexts: Conceptualizing contextual structures and interaction dynamics. Environmental Innovation and Societal Transitions, 16, 51-64.

Bhatti, Y. A. (2012). What is frugal, what is innovation? Towards a theory of frugal innovation. SSRN Scholarly Paper No. ID 2005910. Rochester, NY: Social Science Research Network. Available from: https://papers.ssrn.com/abstract $=2005910$

Bonino, D., Ciaramella, A., \& Corno, F. (2010). Review of the state-of-the-art in patent information and forthcoming evolutions in intelligent patent informatics. World Patent Information, 32(1), 30-38.

Cabero, J. (2006). Bases pedagógicas del e-learning. Revista de Universidady Sociedad del Conocimiento, $3(1), 1-10$.

Carvalho, A. C., Storopoli, J. H., \& Quoniam, L. M. (2014). Prospecção de Patentes para a Solução Sustentável de Problema da Indústria da Construção: O Espaçador de Concreto. Revista Inovação, Projetos e Tecnologias, 2(1), 115-127.

Chesbrough, H. W. (2006). Open Innovation: the New Imperative for Creating and Profiting from Technology. Brighton, MA: Harvard Business Press. 
REGE 27,1

Choi, Y. S., \& Heinemann, A. (2016). Restrictions of competition in licensing agreements: the worldwide convergence of competition laws and policies in the field of intellectual property. European Business Organization Law Review, 17(3), 405-422.

Corrêa, F. C., \& Gomes, S. L. R. (2013). A patente na universidade: sigilo, transparência e direito à informação. VIII ENANCIB (pp. 1-15). Salvador.

CPC (2017). Cooperative patent classification. Available from: www.cooperativepatentclassification. $\mathrm{org} / \mathrm{cpc} / \mathrm{scheme} / \mathrm{G} / \mathrm{scheme}-\mathrm{G} 06 \mathrm{Q} . \mathrm{pdf}$ (1o. de fevereiro de 2017).

Dantas, F. (2004). Responsabilidade social e pós-graduação no Brasil: idéias para (avali)ação. Revista Brasileira de Pós-Graduação, 1(2), 160-172.

Ernst, H. (2003). Patent information for strategic technology management. World Patent Information, 25(3), 233-242.

Ferraz, R. R. N., Quoniam, L. M., \& Maccari, E. A. (2014). A utilização da ferramenta Scriptlattes para extração e disponibilização online da produção acadêmica de um programa Stricto Sensu em Administração. Available from: https://doi.org/10.5748/9788599693100-11CONTECSI/PS-583 (1o. de fevereiro de 2017).

Ferraz, R. R. N., Quoniam, L., Reymond, D., \& Maccari, E. A. (2016). Example of open-source OPS (Open Patent Services) for patent education and information using the computational tool Patent2Net. World Patent Information, 46, 21-31.

Ferraz, R. R. N., Quoniam, L., Pimenta, D. N., Mena-Chalco, J. P., \& Nigro, C. A. (2015). Extração e disponibilização on line de indicadores de desempenho e prospecção dos resultados das pesquisas em dengue com a utilização da ferramenta computacional Scriptlattes. Encontros Bibli: revista eletrônica de biblioteconomia e ciência da informação, 20(43), 93-114.

França, R. O. (1997). Patente como fonte de informação tecnológica. Perspectivas Em Ciência Da Informação, 2(2). Available from: http://portaldeperiodicos.eci.ufmg.br/index.php/pci/article/ view/636

Gartner, I. R., Zwicker, R., \& Rödder, W. (2009). Investimentos em tecnologia da informação e impactos na produtividade empresarial: uma análise empírica à luz do paradoxo da produtividade. Revista de Administração Contemporânea, 13(3), 391-409.

Govindasamy, T. (2002). Successful implementation of e-learning: pedagogical considerations. Internet and Higher Education, 4(3-4), 287-299.

Hassanzadeh, A., Kanaani, F., \& Elahi, S. (2012). A model for measuring e-learning systems success in universities. Expert Systems with Applications, 39(12), 10959-10966.

Hoffmann, M. G., Coral, E., \& Jara, E. (2014). Relações entre P\&D, patentes e exportação em empresas brasileiras ativamente inovadoras. Revista de Negócios, 19(3), 75-90. Available from: https://doi. org/10.7867/1980-4431.2014v19n3p75-90

Hung, J. (2012). Trends of e-learning research from 2000 to 2008: Use of text mining and bibliometrics. British Journal of Educational Technology, 43(1), 5-16.

INPI (2017). Lista dos Códigos - Instituto Nacional da Propriedade Industrial. Recuperado 3 de fevereiro de 2017. Available from: www.marcasepatentes.pt/index.php?section=689 (1o. de fevereiro de 2017).

Jürgens, B., \& Herrero-Solana, V. (2015). Espacenet, patentscope and DEPATISnet: a comparison approach. World Patent Information, 42, 4-12. Available from: https://doi.org/10.1016/j.wpi.2015.05.004

Kallas, P. (2006). Open patent services. World Patent Information, 4(28), 296-304.

Kelly, M. A., Hopwood, N., Rooney, D., \& Boud, D. (2016). Enhancing students' learning through simulation: dealing with diverse, large Cohorts. Clinical Simulation in Nursing, 12(5), 171-176.

Kim, Y. G., Suh, J. H., \& Park, S. C. (2008). Visualization of patent analysis for emerging technology. Expert Systems with Applications, 34(3), 1804-1812.

Kubota, F. I., \& da Rosa, L. C. (2013). Identification and conception of cleaner production opportunities with the theory of inventive problem solving. Journal of Cleaner Production, 47, 199-210. 
Landmann, A., Havron, W. S., Patel, A., Thompson, B. M., \& Lees, J. S. (2016). Medical student Implementation expectations from surgical education: A two-year institutional experience. American Journal of Surgery, 212(6), 1265-1269.

Larose, D. T. (2014). Discovering knowledge in data: an introduction to data mining. Hoboken, NJ: John Wiley \& Sons.

Lastres, H. M., Cassiolato, J. E., Lemos, C., Maldonado, J., \& Vargas, M. A. (1999). Globalização e inovação localizada. Available from: www.ie.ufrj.br/redesist/P1/texto/NT01.PDF (1o. de fevereiro de 2017).

Laursen, K., \& Salter, A. (2006). Open for innovation: The role of openness in explaining innovation performance among UK manufacturing firms. Strategic Management Journal, 27(2), 131-150.

Matias-Pereira, J. (2011). A gestão do sistema de proteção à propriedade intelectual no Brasil é consistente?. Independent Journal of Management \& Production, 45(3), 567-590. Available from: https://doi.org/10.14807/ijmp.v2i2.24

Mazieri, M. R. (2016). Patentes e inovação frugal em uma perspectiva contributiva (Tese (Doutorado em Administração), Universidade Nove de Julho). Recuperado de. Available from: http://biblio tecatede.uninove.br/handle/tede/1600

Mazzieri, M. R., Quoniam, L., \& Santos, A. M. (2016). Inovação a partir das informações de patentes: proposição de modelo Open Source de Extração de Informações de Patentes (Patent Crawler). Revista Gestão \& Tecnologia, 16(1), 76-112.

Melo, E. M., Cajavilca, E. S. R., Sales, G. F., Marques, N. d. S., Lobo, R. d. S., \& Santana, V. G. (2014). Análise das patentes depositadas por universidades federais brasileiras no banco de dados do Espacenet. Cadernos de Prospecção, 6(4), 561.

Morescalchi, A., Pammolli, F., Penner, O., Petersen, A. M., \& Riccaboni, M. (2015). The evolution of networks of innovators within and across borders: evidence from patent data. Research Policy, 44(3), 651-668.

Nigro, C. A. (2017). Uso das ferramentas computacionais Scriptlattes, Scriptgp e Patent2net para análise da produção bibliográfica e tecnológica sobre a dengue. Available from: http:// repositorio.uninove.br/xmlui/handle/123456789/1242 (1o. de fevereiro de 2017).

Oliveira, M. A. N. (2007). Educação à Distância como estratégia para a educação permanente em saúde: possibilidades e desafios. Revista Brasileira de Enfermagem, 60(5), 585-589.

PatBase (2017). PatBase classification lookup. Available from: www.patbase.com/linkclass.asp?CCC= IPC\&CLASS=G09B9\%2F00 (1o. de fevereiro de 2017).

Quoniam, L., Kniess, C. T., \& Mazzieri, M. R. (2014). A patente como objeto de pesquisa em Ciências da Informação e Comunicação. Encontros Bibli: revista eletrônica de biblioteconomia e ciência da informação, 19(39), 243-268.

Reymond, D., \& Dematraz, J. (2015). Using networks in patent exploration: application in patent analysis: the democratization of 3D printing. Pesquisa Brasileira Em Ciência Da Informação e Biblioteconomia, 19(40), 117-144. Available from: http:/periodicos.ufpb.br/ojs2/index.php/ pbcib/article/view/23256

Reymond, D., \& Quoniam, L. (2016). A new patent processing suite for academic and research purposes. World Patent Information, 47, 40-50. Available from: https://doi.org/10.1016/j.wpi.2016.10.001

Ruiz, J. G., Mintzer, M. J., \& Leipzig, R. M. (2006). The impact of e-learning in medical education. Academic Medicine, 81(3), 207-212.

Serafini, M. R., Paixao, A. E. A., Oliveira-Junior, A. M., Santos, J. A. B., \& Da Silva, G. F. (2012). Avaliação de tecnologias em dessalinização de água a partir da análise dos pedidos de patentes. GEINTEC - Gestão, Inovação e Tecnologias, 2(1), 42-51.

Simões, R., Baessa, A., Campolina, B., \& Silva, L. (2002). A distribuição espacial da produção científica e tecnológica brasileira: uma descrição de estatísticas de produção local de patentes e artigos científicos. Revista Brasileira de Inovação, 1(2), 225-251. 
REGE 27,1

Soni, P., \& Krishnan, R. T. (2014). Frugal innovation: aligning theory, practice, and public policy. Journal of Indian Business Research, 6(1), 29-47.

Storopoli, J. E. (2016). O uso do Knowledge Discovery in Database (KDD) de informações patentárias sobre ensino a distância: contribuições para instituições de ensino superior. Available from: http://bibliotecatede.uninove.br/handle/tede/1517 (1o. de fevereiro de 2017).

Sun, Y. (2003). Determinants of foreign patents in China. World Patent Information, 25(1), 27-37.

Teece, D. J. (2007). Explicating dynamic capabilities: the nature and microfoundations of (sustainable) enterprise performance. Strategic Management Journal, 28(13), 1319-1350.

Teixeira, R. C., \& Souza, R. R. (2013). O uso das informações contidas em documentos de patentes nas práticas de Inteligência Competitiva: apresentação de um estudo das patentes da UFMG. Perspectivas em Ciência da Informação, 18(1), 106-125.

Thomson (2017). Patent kind codes by country. London: Thomson Scientific. Available from: www. thomsonfilehistories.com/docs/RESOURCES_Kind \%20Codes\%20by \%20Country.pdf

Tseng, Y.-H., Lin, C.-J., \& Lin, Y.-I. (2007). Text mining techniques for patent analysis. Information Processing \& Management, 43(5), 1216-1247.

Welsh, E. T., Wanberg, C. R., Brown, K. G., \& Simmering, M. J. (2003). E-learning: emerging uses, empirical results and future directions. International Journal of Training and Development, $7(4), 245-258$.

White, M. J. (2006). esp@cenet Europe’s network of patent databases. Munich: European Patent Office. Available from: https://doi.org/10.5062/F4F47M2H

WIPO (2016). Recommended standard code for the identification of different kinds of patent documents. Geneve: World Intellectual Property Organization. Available from: www.wipo.int/export/sites/ www/standards/en/pdf/03-16-01.pdf

Zendejas, B., Brydges, R., Wang, A. T., \& Cook, D. A. (2013). Patient outcomes in simulation-based medical education: a systematic review. Journal of General Internal Medicine, 28(8), 1078-1089.

Zhang, D., Zhao, J. L., Zhou, L., \& Nunamaker, J. (2004). Can e-learning replace classroom learning?. Communications of the ACM, 47(5), 75-79.

\section{Corresponding author}

Renato Ribeiro Nogueira Ferraz can be contacted at: renatobio@hotmail.com

Associate Editor: Marcelo Pedroso

For instructions on how to order reprints of this article, please visit our website:

www.emeraldgrouppublishing.com/licensing/reprints.htm

Or contact us for further details: permissions@emeraldinsight.com 